\title{
Inequality and the Import Demand in Turkey
}

\section{Türkiye'de İthalat Talebi ve Eşitsizlik}

\author{
Zühal ÖZBAY DAŞ ${ }^{1} \odot$
}

\begin{abstract}
The study aims to see whether the long-run relation between inequality and import demand exists in Turkey. The Autoregressive Distributed Lag (ARDL) cointegration technique is used in this study to estimate the long-run relationships between real imports, income, relative price, real exports, and inequality for the period 1982-2015. The results revealed that the income elasticity of imports is greater than one as the literature suggests. The sign of the coefficient of relative price and its magnitude is also compatible with the literature, while it is not statistically significant. However, the results further reflect that inequality is positively associated with real imports in Turkey contrary to assumptions of the relation between inequality and imports that is found to be negative for lower income countries in some studies. Short-run coefficients reflect that real income and relative prices are associated with real imports, whereas exports and not surprisingly, inequality variables are not in the shortrun. The coefficient of income parameter is less in magnitude in the short-run but still greater than one. However, the sign of the coefficient of the relative price turns out to be positive in the short-run.
\end{abstract}

Keywords: Import demand, Inequality, Cointegration JEL Classification: F14, D63

\section{ÖZ}

Bu çalışmanın amacı, Türkiye'de eşitsizlik ve ithalat talebi arasında uzun vadeli bir ilişkinin olup olmadığını anlamaktır. Bu çalışmada, 1982-2015 döneminde reel ithalat, reel gelir, nispi fiyatlar, reel ihracat ve eşitsizlik arasındaki uzun dönemli ilişkileri tahmin etmek için ARDL eşbütünleşme tekniği kullanılmıştır. Sonuçlar, literatür ile uyumlu bir şekilde ithalatın gelir esnekliğinin birden fazla olduğunu göstermiştir. Göreli fiyatların esneklik katsayısı literatürle uyumlu olarak birden az bulunsa da istatistiksel olarak anlamlı çıkmamaktadır. Ancak sonuçlar, göreli düşük gelirli ülkeler için eşitsizlik ve ithalat arasındaki ilişkiyi negatif bulan birtakım çalışmaların aksine Türkiye'de, eşitsizlik ve reel ithalat arasında pozitif bir ilişki olduğunu göstermektedir. Kısa dönem katsayıları ithalatın, reel gelir ve göreli fiyatlar ile ilişkili olduğunu göstermektedir, fakat ithalat şaşırtıcı olmayan bir şekilde ihracat ve eşitsizlik ile kısa dönemde ilişkili değildir. Gelirin kısa
${ }^{1}$ Dr., Fenerbahçe University, Faculty of Economics and Administrative Sciences, Department of Economics, Istanbul, Turkey

ORCID: Z.Ö.D. 0000-0002-8135-047X

\section{Corresponding author:}

Zühal ÖZBAY DAŞ,

Fenerbahçe University, Faculty of Economics and Administrative Sciences, Department of Economics, Istanbul, Turkey

E-mail: zuhal.ozbay@fbu.edu.tr

Submitted: 28.05.2021

Revision Requested: 19.10.2021

Last Revision Received: 29.11.2021

Accepted: 05.12.2021

Citation: Ozbay-Das, Z. (2021). Inequality and the import demand in Turkey. İstanbul iktisat Dergisi - Istanbul Journal of Economics, 71(2), 395-410.

https://doi.org/10.26650/ISTJECON2021-943291 
dönem katsayısı, uzun dönem katsayısından daha düşük, fakat hala birden büyüktür. Diğer yandan, göreli fiyatların katsayısı kısa dönemde pozitife dönmektedir.
Anahtar kelimeler: İthalat talebi, Eşitsizlik, Eşbütünleşme

JEL Sınıflaması: F14, D63 


\section{Introduction}

Countries with different economic development levels have experienced different inter and intra trade relations with the rest of the world. As is widely known, technological differences and factor endowments play greater roles in trade relations, but demand differences are also of concern in many studies regarding international trade (Mitra and Trindade, 2005, p. 1254). Therefore, consumers' behavior matters in determining the import demand function (Mitra and Trindade, 2005). From this point of view, the influence of inequality on the import demand function has gained importance in the many research done so far (Mitra and Trindade, 2005; Adam, Katsimi and Moutos, 2012; Ciani 2021).

The paper aims to analyze the effects of inequality on import demand for Turkey, based on the arguments of Adam et al. (2012) who maintained that the import demand function for the country is changed according to the level of development through its interaction with income inequality. They stated that an increase in income inequality leads to an increase in imports for high income countries, whereas the effect of inequality on imports is negative for low-income countries (Adam et al., 2012, p. 675). They further exemplified this by comparing a high-income country, Germany for instance, which produces and exports mostly high-quality and high-priced "vertically differentiated products" such as high quality automobiles, and a low-income country, which produces low quality and low priced "vertically differentiated products," such as low quality automobiles. Adam et al. (2012) also assumed that "under standard preference structures, highincome households will be consuming the high quality variety, whereas among low-income households only those with strong preferences for the differentiated good will be consuming the high quality variety" (Adam et al., 2012, p. 677).

According to their analysis, if the income inequality level in the high-income country changed and the income of high-income households increased, but lowincome households experienced a decrease in their income, then low-income households would demand more imported, "low-quality variety of differentiated" products (Adam et al., 2012, p. 678). On the contrary, if a domestic country 
produces low quality goods, then an increase in income inequality would lead to a decrease in imports (Adam et al., 2012). Therefore, this study is focused on how inequality affects import demand in Turkey as an emerging economy.

In this context, the next section presents a literature review. The third section is devoted to data used in the analysis. The fourth section presents an empirical model and its results for the years between 1982 and 2015, and the relation of inequality on imports is analyzed through Auto-Regressive Distributed Lags (ARDL). The last section concludes.

\section{Literature Review}

In the literature, there are many studies estimating the price and income elasticities of imports and exports for various economies (Houthakker and Magee, 1969; Hong, 1999; Emran and Shilpi, 2010). Goldstein and Khan (1985) covered many empirical studies by that time and discussed different variables in the formation of "demand and supply functions of imports and exports" in detail. Some research particularly focused on the import demand for developing economies (Khan, 1974; Bahmani-Oskooee, 1986), and the results, to some extent, reflect some slight differences in income and price elasticities across different income levels at different periods. Hong (1999), for instance, pointed out that "income elasticity in developed economies, on average, could be higher than that in developing economies. However, the income elasticities of imports across countries should not be too different" (Hong, 1999, p.10). Indeed, Emran and Shilpi (2010) estimated income and price elasticities of imports for Sri Lanka and India by using the ARDL and FM-ADL techniques and found out that on average, income elasticity is estimated at 1.16, which is consistent with the "conventional wisdom of long-run unitary income elasticity." Price elasticity is, on average, estimated at -0.78 , which the authors stated that the results are much higher than previous studies for these countries. Bahmani-Oskooee (1998) estimated long-run price elasticities by applying Johansen and Juselies' method and showed that the Marshall-Lerner condition holds for developing economies (Bahmani-Oskooee, 1998, p. 90). Khan and Knight (1988) developed the model 
by incorporating two key feedback relationships between export and imports and estimated for 34 developing countries. They concluded that "import compression adversely affects export performance" (Khan and Knight, 1988, p. 315). Slower export growth further leads to import compression because of a decrease in the foreign exchange reserves (Khan and Knight, 1988).

Katsimi and Moutos (2011) stated that import demand functions are usually formed on the imperfect substitutes model. ${ }^{1}$ In these approaches, households who have a homothetic utility function maximize their utility subject to budget constraint, so total imports are determined by the function of income and relative prices. Adam et al. (2012) argued that the implicit assumption is its ignorance of the effects of inequality on import demand. Francois and Kaplan (1996) underlined the importance of income distribution on trade expenditures. Mitra and Trindade (2005) further analyzed "the role of inequality in the determination of trade flows and patterns" (Mitra and Trindade, 2005, p. 1253). Adam et al. (2012) included income inequality as a primary determinant of the volume of imports. As stated above, they argued that the effects of inequality on imports change according to the country's level of economic development. Recently, many research has been done on gravity models explaining the effects of various relations on the volume of bilateral trade flows. Dalgin, Trindade and Mitra (2008) estimated gravity models and showed that "inequality affects the structure and the origin of trade flows" (Dalgin et al., 2008, p. 773). Bekkers et al. (2012) used panel data, including Turkey, and showed "the negative effect of inequality" on import unit values. Recently, Ciani (2021) found that income inequality plays a significant role in import demand by inducing "quality and unit value differentials across markets."

Various researchers have also estimated the Turkish import demand function. Tansel and Togan (1987) focused on aggregate export and import demand functions in Turkey which showed evidence of price inelastic import demand. Karaman and Özkale (2006) also found that import demand in Turkey is income elastic, whereas price is inelastic. Kotan and Saygll (1999) analyzed the import

\footnotetext{
${ }^{1}$ Imports and domestic goods are not perfect substitutes.
} 
demand function for the period of 1987-1999 in Turkey with the scope of longrun and short-run and concluded that the exchange rate is the primary determinant of the import demand in the short-run. On the other hand, they showed that "domestic demand and stock of international reserves are the main determinants of import demand" (Kotan and Saygll, 1999, p. 21) in the long-run. Şimşek and Kadılar (2004) analyzed the long-run relations between relative price, income, and import demand and found that the Marshall-Lerner condition holds for Turkey. Aydın et al. (2004) assessed the determinants of import demand and export supply and concluded that the real exchange rate is statistically determinant for imports in Turkey. Qğuş and Sohrabji (2009) analyzed "exchange rate and income elasticities of Turkish exports and imports" and found that income elasticity for imports is greater than exports for 1999-2008. Alakbarov, Özkaya, Gündüz and Şaşmaz (2018) also tested long-run and short-run income and price elasticities for 2001-2015 in Turkey and found that income elasticity of the import demand function is higher than price elasticity, as is consistent with the previous studies. Çulha, Eren and Ögünç (2019) also estimated the import demand function in Turkey for 2003-2018 with the newly defined national data. Their results for total imports are in line with the previous studies in terms of income and price elasticities. Çulha et al. (2019) further extended the analysis by estimating the import demand functions of the three broad categories of goods: consumption, investment, and intermediate goods. Demir (2020) analyzed the relation between import consumption and income inequality for some selected economies and found that the causality from income inequality to import demand is not evident, but the opposite direction is. As far as the author's knowledge goes, the long-run relation between the income inequality and import demand function has not been investigated for Turkey, except in the panel analyses stated above. In this analysis, the long-run relation between income inequality and import demand is investigated through an ARDL analysis.

\section{Data}

The analysis is based on time series data for the period of 1982-2015. Value of total imports data is taken from TURKSTAT. Nominal import values are to be 
deflated by the import unit value index $\left(2010^{2}\right.$, USD). Real income is real GDP 2010 US dollars reported in the World Development Indicators Database. The relative price of imports is calculated as import value index over GDP deflator which is taken from the World Development Indicator Database as well. The value of total exports data are taken from TURKSTAT and deflated by the export unit value index from TURKSTAT ${ }^{3}$. The total exports are also put into the analysis, as Sekmen and Saribas (2007) showed the existence of "cointegration between exports and imports" for 1998-2006 in Turkey.

Following Adam et al., (2012) the Estimated Household Income Inequality Data Set (EHII) from the University of Texas Inequality Project (UTIP) (2015) is used for the measurement of inequality. This data set is "derived from the econometric relationship between Theil, other control variables, and the World Bank's Deininger \& Squire dataset" (Elgin and Elveren, 2019, p.15). Only the 2001 data is missing for the given period and data is available up to 2015 for Turkey.

\section{Empirical Model and Results}

To see whether the long-run relation between inequality and import demand exists, the following empirical model is constructed:

$$
L M_{t}=\beta_{0}+\beta_{1} L Y_{t}+\beta_{2} L R P_{t}+\beta_{3} L R X_{t}+\beta_{4} L I N E Q_{t}+t+u_{t}
$$

where $t=1, \ldots \tau \ldots T$ denotes time period, LM denotes log of total real imports in terms of dollars, LY denotes log real GDP based on 2010 USD constant dollars, LRP refers to log of import unit value index over GDP deflator, LRX denotes log of total real exports in terms of dollars, LINEQ denotes log of household income inequality, $\mathrm{t}$ is time trend.

\footnotetext{
2 All indexes are transformed into 2010 base year.

3 All values and indices of export and import data are in terms of US dollars.

${ }^{4}$ The model is estimated without including inequality and the results are to be found in the Appendix.
} 
Previous studies for the Turkish import demand function reflect that there is a long-run relationship between price and income and, in most of the studies, while income is elastic, price is inelastic (Karaman and Özkale, 2006). The existence of the long-run relation between exports and imports is anticipated based on the Sekmen and Sarıbass (2007) study. The relation between real imports and inequality, as Adam et al. (2012) argued, could change according to the economic development level of the country as discussed above. Adam et al. (2012) proposed that an increase in inequality may decrease real imports in developing economies. In their studies, Turkey is categorized as a low income country. Moreover, Erlat and Erlat (2012) measured intra-industry trade for the Turkish manufacturing sector for 1987-2001 and found that "vertical industries dominated horizontal industries and low quality vertical industries dominated high quality vertical industries" (Erlat and Erlat, 2012, p. 149). Thus, there is a possible inverse relation between income inequality and import level expected in Turkey.

The Autoregressive Distributed Lag (ARDL) cointegration technique is used to estimate the long-run relationships between real imports, income, relative price, real exports, and inequality in this study. There are also many studies using the ARDL technique to estimate the import demand function of countries (Emran and Shilpi, 2010; Durmaz and Lee, 2015; Rashid and Razzaq, 2010). In the ARDL cointegration method, all variables should not necessarily have the same integration of order. The variables could have different integration of orders i.e., $\mathrm{I}(0), \mathrm{I}(1)$ or mixed (Peasaran and Shin, 1998). Besides, the sample size is relatively small in this study (Ozbay Das, 2020) and Narayan (2006) pointed out that "with the ARDL framework, the OLS estimators of the short-run parameters are $\sqrt{\mathrm{T}}$ consistent and the ARDL based estimators of the long-run coefficients are superconsistent in small sample sizes" (2006, p.400).

The following $\operatorname{ARDL}\left(p_{1}, p_{2}, p_{3}, p_{4}\right)$ specification of Equation 1 is estimated:

$$
L M_{t}=\beta_{0}+\sum_{i=1}^{p_{1}} \beta_{1} L Y_{t-i}+\sum_{i=0}^{p_{2}} \beta_{2} L R P_{t-i}+\sum_{i=0}^{p_{3}} \beta_{3} L R X_{t-i}+\sum_{i=0}^{p_{4}} \beta_{4} L I N E Q_{t-i}+t+\mu_{t}
$$


Short run model which is to estimate the error correction term is represented as follows:

$$
\begin{aligned}
\Delta L M_{t}=\alpha_{0}+ & \sum_{i=1}^{m} \alpha_{1} \Delta L M_{t-i}+\sum_{i=0}^{n} \alpha_{2} \Delta L Y_{t-i}+\sum_{i=0}^{n} \alpha_{3} \Delta L R P_{t-i}+\sum_{i=0}^{n} \alpha_{4} \Delta L R X_{t-i} \\
& +\sum_{i=0}^{n} \alpha_{5} \Delta L R X_{t-i}+\alpha_{6} E C T_{t-i}+\varepsilon_{t}
\end{aligned}
$$

Table 2 reflects the Augmented Dickey Fuller (ADF) tests of unit roots, and the unit root tests shows that variables are integrated of order one I (1) (The PhillipPerron unit root tests also reflect the evidence of I(1) for all variables). Thus, the ARDL cointegration technique could apply to this study. Moreover, ARDL bound tests in table 2 reveal that the hypothesis of no long-run relationship is rejected for this model. The Schwarz Criteria is used for model selection.

Table 1: ADF tests of unit roots in annual data (1982-2015)

\begin{tabular}{|l|c|c|c|c|}
\hline Variables & \multicolumn{2}{|c|}{ ADF tests (t statistics) in level data } & \multicolumn{2}{c|}{ ADF tests (t statistics) in first-differenced data } \\
\hline & Constant & Constant and trend & Constant & Constant and trend \\
\hline LM & $-1.75(0.39)$ & $-2.99(0.15)$ & $-8.08^{* *}(0.00)$ & $-8.38^{* *}(0.00)$ \\
LY & $0.03(0.95)$ & $-2.36(0.39)$ & $-5.92^{* *}(0.00)$ & $-5.84^{* *}(0.00)$ \\
LRP & $-2.46(0.13)$ & $-0.003(0.99)$ & $-3.69^{\star *}(0.009)$ & $-4.40^{* *}(0.007)$ \\
LRX & $-1.64(0.44)$ & $-1.36(0.85)$ & $-5.28^{\star *}(0.00)$ & $-5.73^{\star *}(0.00)$ \\
LINEQ & $-1.02(0.73)$ & $-0.57(0.97)$ & $-3.64^{\star *}(0.01)$ & $-4.43^{\star *}(0.01)$ \\
\hline
\end{tabular}

$* * * 1 \%$ significance, $* * 5 \%$ significance, $* 10 \%$ significance. Probability values are in parentheses. All variables are also found to be integrated of order one I(1) according to Phillips-Perron unit root tests.

Table 2: ARDL Bound Tests

\begin{tabular}{|l|c|c|c|}
\hline \multicolumn{4}{|l|}{ Model 1 (With Inequality) } \\
\hline F Statistic 6.56 k 4 n=30 & $10 \%$ & $5 \%$ & $1 \%$ \\
\hline $\mathrm{I}(0)$ & 2.68 & 3.05 & 3.81 \\
\hline $\mathrm{I}(1)$ & 3.53 & 3.97 & 4.92 \\
\hline
\end{tabular}

Notes: Number of observations, $n=30$, the number of explanatory variables, $k=4$

Diagnostic tests show that the null hypothesis of no heteroscedasticity cannot be rejected, and the model does not suffer from serial correlation. The Jarque Bera test reveals that the normality assumption holds (see table 3 ). The results of 
the CUSUM and CUSUMQ of the ARDL models (see Figure 1) indicate that the model is stable over time.

Table 3: Breusch-Pagan-Godfrey Heteroskedasticity Test and Serial Correlation LM Test and Jarque-Bera Best

\begin{tabular}{|c|c|c|c|}
\hline \multicolumn{4}{|c|}{ Heteroskedasticity Test: Breusch-Pagan-Godfrey } \\
\hline F statistics (Model 1) & 1.51 & Prob $F(10,19)$ & 0.21 \\
\hline \multicolumn{4}{|c|}{ Breusch-Godfrey Serial Correlation LM Test: } \\
\hline F statistics (Model 1) & 1.49 & Prob F(2,17) & 0.25 \\
\hline \multicolumn{4}{|l|}{ Jarque Bera } \\
\hline F statistics (Model 1) & 0.173 & & 0.91 \\
\hline
\end{tabular}

Figure 1. CUSUM and CUSUM of Squares for the $1^{\text {st }}$ Model
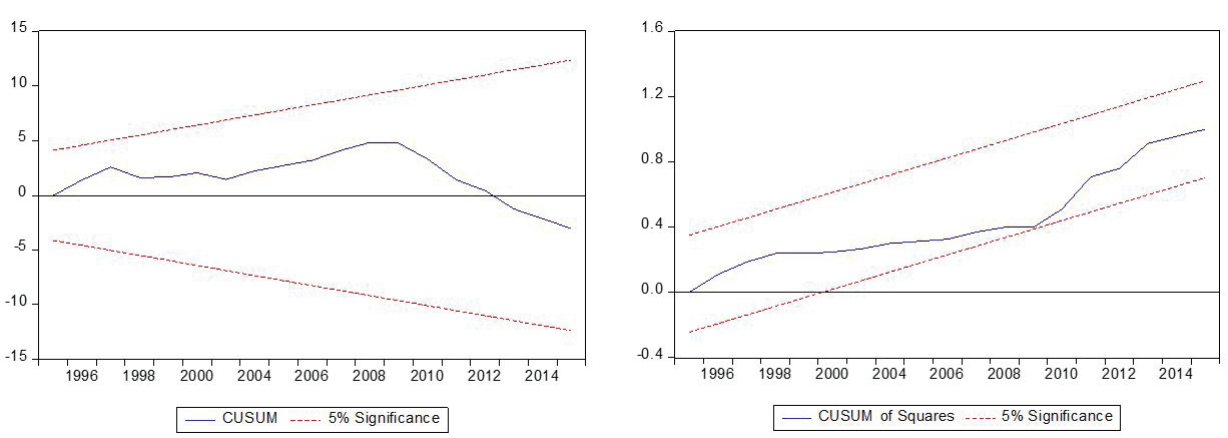

Empirical results in Table 4 shows that real income is significant and in line with the previous studies; that is, the income elasticity of imports is greater than one, and the sign is positive. The sign of the coefficient of relative price and its magnitude (less than 1, price inelastic) is also compatible with the literature; however, it is not significant. The results also reveal that the long-run relation between exports and imports does not exist during the period.

As mentioned above, inequality may decrease real imports in developing economies, but for this period, inequality is positively associated with real imports. Therefore, for Turkey, an increase in income inequality may not trigger the consumption of domestic products that are assumed to be a low-quality variety of differentiated products. Instead, inequality may increase the demand 
for imported low quality products that are relatively lower-priced than the domestic ones, or increase the demand for imported high-quality products, due to the period selected in this study. Inequality had gradually increased since $1989^{5}$ when Turkey became fully integrated into the world economy through financial liberalization. The trend started to decrease in 2003. Therefore, the selected period itself might be the reason for this outcome. As a result, further research, understanding the relation between inequality and import demand for some broad categories in Turkey, is recommended to see their interaction clearly.

ECT $(-1)$ is highly significant and the coefficient of ECT (-1) implies that the adjustment process is relatively rapid at $36 \%$. The short-run coefficients reflect that real income and relative prices are associated with real imports, while exports and, not surprisingly, inequality, are not associated in the short-run. Sekmen and Sarı (2007) pointed out that bidirectional causality between exports and imports exists and stated that "exports increase the capacity to import, and besides real imports have usually an important positive on industrial and non-industrial real Gross Domestic Product" (p. 76). Therefore, the association between exports and imports might not exist in the short-run. The coefficient of income parameter is less in magnitude in the short-run, but still greater than 1 . However, the sign of the coefficient of the relative price turns out to be positive in the short-run and significant. Durmaz and Lee (2015) pointed out that the positive association between price and imports might result from the slow adjustment process in the short-run and in turn this might lead to an increase "in import expenditure bills" (p.215). Thus, the relation between relative prices and import changes according to the time period in Turkey.

\footnotetext{
5 The time period which is selected in this paper coincides with significant developments in the Turkish economy. After the coup d'état in 1980, Turkey changed its economics paradigm, abandoned its import substitution economic policy, and adopted export-led growth strategies. Full integration into the world economy concluded at the end of $1980 \mathrm{~s}$, with the implementation of policies stimulating financial liberalization. In 1995, a customs union between Turkey and the EU was signed, which affected Turkey's trade volume and trade structure.
} 
Table 4: Empirical Results

\begin{tabular}{|l|c|}
\hline Long-run Coefficients \\
\hline Variable & 1 \\
\hline LY & $2.67^{* *}(1.13)$ \\
\hline LRP & $-0.07(0.06)$ \\
\hline LRX & $0.16(0.45)$ \\
\hline LINEQ & $3.10^{* *}(1.37)$ \\
\hline$t$ & $-0.07(0.05)$ \\
\hline ECT(-1) & $-0.36^{* * *}$ \\
\hline
\end{tabular}

Notes: For the model selection, Schwarz Criteria (SC) is used and the model is SC $(1,2,1,0,1)$. ${ }^{* *} 1 \%$ significance, ${ }^{* *} 5 \%$ significance, ${ }^{*} 10 \%$ significance. Standard errors in parentheses.

Table 5: Short-run Coefficients

\begin{tabular}{|l|c|}
\hline Variable & 1 \\
\hline$D(L Y)$ & $2.11^{* * *}(0.24)$ \\
\hline$D(L Y(-1))$ & $-0.54^{* *}(0.22)$ \\
\hline$D(L R P)$ & $0.12^{* * *}(0.04)$ \\
\hline$D($ LRX $)$ & $-0.01(0.11)$ \\
\hline$D($ LINEQ $)$ & $-0.24(0.57)$ \\
\hline$c$ & $-24.03^{* * *}(3.67)$ \\
\hline
\end{tabular}

Notes: ${ }^{* *} 1 \%$ significance, ${ }^{* *} 5 \%$ significance, $* 10 \%$ significance. Standard errors in parentheses.

\section{Concluding Remarks}

The trade structure of a country is determined by many factors, and as theory suggests income and relative price of goods and services play a significant role in the trade volume of a country. Indeed, in this study, the empirical results show that real income is found to be significant, the income elasticity of imports is greater than one, and the sign is in line with previous studies. The sign of the coefficient of the relative price and its magnitude (less than 1 , price inelastic) is also compatible with the literature, even though it is not significant. However, not only price and income, but also demand differences and consumer preferences have a substantial impact particularly on demand for imports as discussed above. Adam et al. (2012) further argued that the import demand function for a country is changed according to the level of development through its interaction with income inequality. In that sense, this paper has incorporated inequality parameters into the import demand function in Turkey to see whether a long-term relationship 
between inequality and real imports exists. The results reveal that there is a positive association, contrary to what Adam et. $\mathrm{Al}$ (2012) suggested.

Inequality may have different impacts on different categories of goods and services. In particular, its effect may be differentiated among consumer goods, investment goods and others, and may even be differentiated among some consumer products. Other than that, Turkey is categorized as a middle highincome country by the World Bank, therefore, inequality may promote imports of relatively lower priced products from lower income countries over domestic products. Thus, further research on these issues is recommended.

\section{Appendix}

Table A1: Long Run and Short Run Coefficient for the Estimation Without Inequality

\begin{tabular}{|l|c|}
\hline Variable & Long Run \\
\hline LY & $8.33(13)$ \\
\hline LRP & $-0.55(0.9)$ \\
\hline LRX & $-1.37(3.73)$ \\
\hline$t$ & $-0.34(0.6)$ \\
\hline ECT $(-1)$ & $-0.08^{\star \star \star}$ \\
\hline
\end{tabular}

Notes: For the model selection, Schwarz Criteria (SC) is used, and the model is $\mathrm{SC}(1,2,1,0)$. The Jarque Berra tests reflect that the normality assumption holds in this model. The model does not suffer from serial correlation and heteroscedasticity (see Table A3). The results of CUSUM and CUSUMQ of the ARDL models (see Figure A3) indicate that the model is stable over time.

*** $1 \%$ significance, ${ }^{* *} 5 \%$ significance, ${ }^{*} 10 \%$ significance. Standard errors in parentheses.

\begin{tabular}{|l|l|}
\hline Variable & Short Run \\
\hline$D(L Y)$ & $2.41^{\star \star \star}(0.27)$ \\
\hline$D(L Y(-1))$ & $-0.76^{\star \star *}(0.20)$ \\
\hline$D(L R P)$ & $0.13^{\star *}(0.05)$ \\
\hline$D(L R X)$ & $-0.14(0.13)$ \\
\hline$C$ & $-13.7^{\star * \star}(2.79)$ \\
\hline
\end{tabular}

Notes: ${ }^{* *} 1 \%$ significance, ${ }^{* *} 5 \%$ significance, $* 10 \%$ significance. Standard errors in parentheses. 
Table A2: ARDL Bound Tests for the Second Model (Without Inequality)

\begin{tabular}{|l|l|l|l|}
\hline \multicolumn{4}{|l|}{ Model 2 (Without Inequality) } \\
\hline F Statistic 4.39 k 3 n=32 & $10 \%$ & $5 \%$ & $1 \%$ \\
\hline$I(0)$ & 2.97 & 3.38 & 4.3 \\
\hline$I(1)$ & 3.74 & 4.23 & 5.23 \\
\hline
\end{tabular}

Notes: Number of observations, $n=32$, the number of explanatory variables, $k=3$

\section{Table A3: Breusch-Pagan-Godfrey Heteroskedasticity Test and Serial Correlation LM Test and Jarque-Bera Test}

\begin{tabular}{|c|c|c|c|}
\hline \multicolumn{4}{|c|}{ Heteroskedasticity Test: Breusch-Pagan-Godfrey } \\
\hline F statistics (Model 2) & 0.95 & Prob F(8.23) & 0.49 \\
\hline \multicolumn{4}{|c|}{ Breusch-Godfrey Serial Correlation LM Test: } \\
\hline F statistics (Model 2) & 1.24 & Prob F(2.21) & 0.31 \\
\hline \multicolumn{4}{|l|}{ Jarque Bera } \\
\hline F statistics (Model 2) & 3.24 & & 0.197 \\
\hline
\end{tabular}

Figure A1. CUSUM and CUSUM of Squares in the Second Model (Without Inequality)
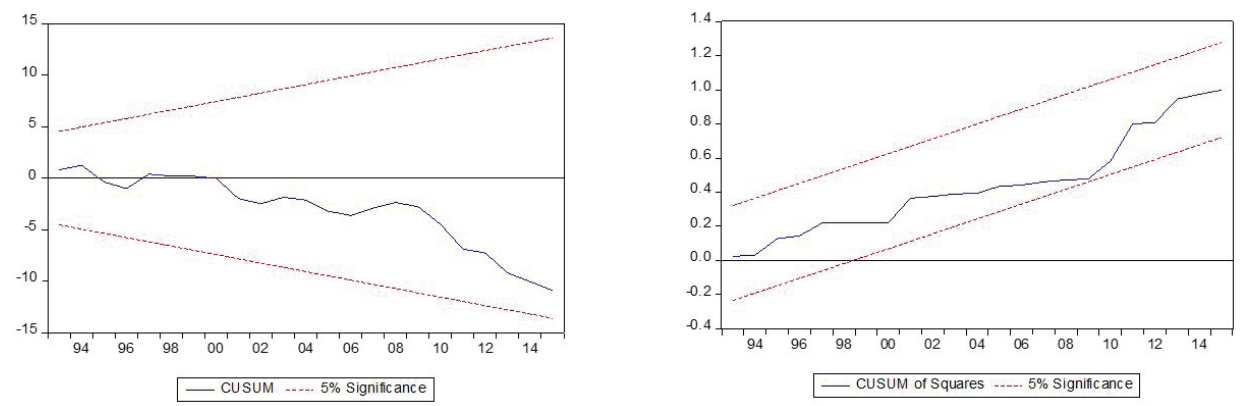

\footnotetext{
Acknowledgement: I would like to thank to Dr. Gülşah Özşahin, Assist. Prof. Dr. Department of Economics at Kırklareli University for her support and comments. I also would like to thank to Dr. Buket Alkan, Assist. Prof. Dr. Department of International Finance and Banking at Fenerbahce University for her valuable comments.

Peer-review: Externally peer-reviewed.

Conflict of Interest: The author has no conflict of interest to declare.

Grant Support: The author declared that this study has received no financial support.
} 


\section{References}

Adam, A., Katsimi, M., Moutos, M. (2012). Inequality and import demand function. Oxford Economic Papers, 64(4), 675-701.

Alakbarov, N., Özkaya, H.M., Gündüz \& M. Şaşmaz, Ü.M. (2018). Türkiye'nin ithalat talep fonksiyonunun Yapısal Kırılmalı Eşbütünleşme Analizi ile tahmini. Bolu Abant lizzet Baysal Üniversitesi Sosyal Bilimler Enstitüsü Dergisi, 18(4), 67-84.

Aydın M. F., Çıplak U. \& Yücel M. E. (2004). Export supply and import demand models for the Turkish Economy. Central Bank of The Republic of Turkey, Research Department Working Paper, No: 04 / 09.

Bahmani-Oskooee, M. (1986). Determinants of international trade flows: the case of developing countries. Journal of Development Economics, 20, 107-123.

Bahmani-Oskooee, M. (1998). Cointegration approach to estimate the long-run trade elasticities in LDCs. International Economic Journal 12(3), 89-96.

Bekkers, E., Francois, J. \& Manchin, M. (2012). Import prices, income, and inequality. European Economic Review, 56(4), 848-869.

Ciani, A. (2021). Income inequality and the quality of imports. Review of World Economics, 157, 375416 DOI:10.1007/s10290-020-00401-2.

Çulha, Y.Ö., Eren O. \& Öğünç, F. (2019). Import demand function for Turkey. Central Bank Review, 19(1), 9-19.

Dalgin, M., Trindade, V., \& Mitra, D. (2008). Inequality, nonhomothetic preferences and trade: A gravity approach. Southern Economic Journal, 74(3), 747-74.

Demir, M.A. (2020). Gelir dağılımı eşitsizliği ve lüks mal ithalatı arasında panel nedensellik analizi. Akademik Araştırmalar ve Çalışmalar Dergisi, 12(23), 419 - 430.

Durmaz, N \& Lee, J. (2015). An empirical analysis of import demand function for Turkey: An ARDL Bounds Testing approach. The Journal of Developing Areas, 49(4), 215-226.

Elgin, C. \& Elveren, Y.A. (2019). Informality, inequality and feminization of labor. Political Economy Research Institute, Working Paper Series, No: 483.

Emran, M.S. \& Shilpi, F. (2010). Estimating import demand function in developing countries: A structural econometric approach with applications to India and Sri Lanka. Review of International Economics, 18(2), 307-319.

Erlat, G.\& Erlat, H. (2012). Measuring vertical and horizontal intra-industry trade: The case for Turkey. International Journal of Economics and Business Research, 4(1/2), 149-165.

Estimated Household Income Inequality Data Set (EHII) retrieved from https://utip.gov.utexas.edu/ datasets.html.

Francois, J., \& Kaplan, S. (1996). Aggregate demand shifts, income distribution, and the Linder Hypothesis. The Review of Economics and Statistics, 78(2), 244-250. doi:10.2307/2109926.

Goldstein, M. \& Khan M.S. (1985). Income and price effects in foreign trade. In R.W. Jones \& P.B. Kenen (eds.) Handbook of International Economics, Vol.2 (pp. 1041-1105), Elsevier Science Publishers B.V. 
Houthakker, S.H. \& Magee, S. (1969). Income and price elasticities in world trade. The Review of Economics and Statistics, 51(2), 111-125.

Hong, P. (1999). Import elasticities revisited. DESA Discussion Paper, No.10.

Katsimi, M. \& Moutos, T. (2011). Inequality and the US import demand function. Journal of International Money and Finance, 30(3), 492-506.

Khan, S.M. (1974). Export and import demand in developing countries. Staff Papers (International Monetary Fund), 21(3), 678-693.

Khan, M.S.\& Knight, M.D. (1988). Import compression and export performance in developing countries. Review of Economic Studies, 70(2), 315-21.

Kotan Z.\& Saygll, M. (1999). Estimating an import function for Turkey. Central Bank of The Republic of Turkey, Discussion Paper, 9909.

Mitra, D. \& Trindade, V. (2005). Inequality and trade. Canadian Journal of Economics, 38(4), $1253-$ 1271.

Narayan, K.P. (2006). Determinants of female fertility in Taiwan, 1966-2001: Empirical evidence from cointegration and variance decomposition analysis. Asian Economic Journal, 20(4), $393-$ 407.

Oğuş Binatll, A. \& Sohrabji, N. (2009). Elasticities of Turkish exports and imports. Working Papers from Izmir University of Economics, No.906.

Ozbay Das, Z. (2020). Determinants of fertility rates in Turkey. International Journal of Public Administration, 43(5), 466-476, DOI: 10.1080/01900692.2019.1676779.

Karaman, F. \& Özkale, L. (2006). Static effects of the EU-Turkey Customs Union. Journal of International Trade and Diplomacy, Turkey Undersecretariat of the Prime Ministry for Foreign Trade, 1, 117-138.

Peasaran, M.H. \& Shin, Y. (1998). An autoregressive distributed-lag modelling approach to cointegration analysis. Econometric Society monographs, 31, 371-413.

Rashid, A. \& Razzaq, T. (2010). Estimating import-demand function in ARDL framework: The case of Pakistan. MPRA Paper No.26079.

Sekmen, F., Saribas, H. (2007). Cointegration and causality among exchange rate, export, and import: Empirical evidence from Turkey. Applied Econometrics and International Development, 7(2),7283.

Şimşek, M. ve Kadılar, C. (2004). Türkiye'nin ihracat talebi fonksiyonunun sınır testi yöntemi ile eşbütünleşme analizi. Doğuş Üniversitesi Dergisi, 5(1), 27-34.

Tansel, A.\& Togan, S. (1987). Price and income effects in Turkish foreign trade. Weltwirtschaftliches Archiv, Bd.123, H.3, 521-534.

Turkish Statistical Institute, TURKSTAT.

World Bank, World Development Indicators. 